February 2005 • NREL/CP-520-36583

\title{
Performance and Reliability of a 1-kW Amorphous Silicon Photovoltaic Roofing System
}

\author{
J. Adelstein and B. Sekulic
}

Prepared for the $31^{\text {st }}$ IEEE Photovoltaics Specialists Conference and Exhibition

Lake Buena Vista, Florida

January 3-7, 2005
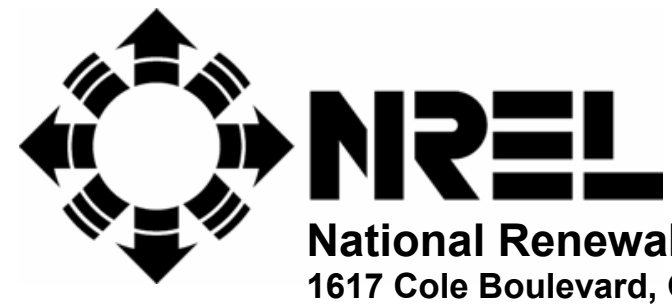

National Renewable Energy Laboratory 1617 Cole Boulevard, Golden, Colorado 80401-3393 303-275-3000 • www.nrel.gov

Operated for the U.S. Department of Energy

Office of Energy Efficiency and Renewable Energy

by Midwest Research Institute $\bullet$ Battelle 


\section{NOTICE}

The submitted manuscript has been offered by an employee of the Midwest Research Institute (MRI), a contractor of the US Government under Contract No. DE-AC36-99G010337. Accordingly, the US Government and MRI retain a nonexclusive royalty-free license to publish or reproduce the published form of this contribution, or allow others to do so, for US Government purposes.

This report was prepared as an account of work sponsored by an agency of the United States government. Neither the United States government nor any agency thereof, nor any of their employees, makes any warranty, express or implied, or assumes any legal liability or responsibility for the accuracy, completeness, or usefulness of any information, apparatus, product, or process disclosed, or represents that its use would not infringe privately owned rights. Reference herein to any specific commercial product, process, or service by trade name, trademark, manufacturer, or otherwise does not necessarily constitute or imply its endorsement, recommendation, or favoring by the United States government or any agency thereof. The views and opinions of authors expressed herein do not necessarily state or reflect those of the United States government or any agency thereof.

Available electronically at http://www.osti.gov/bridge

Available for a processing fee to U.S. Department of Energy and its contractors, in paper, from:

U.S. Department of Energy

Office of Scientific and Technical Information

P.O. Box 62

Oak Ridge, TN 37831-0062

phone: 865.576 .8401

fax: 865.576.5728

email: mailto:reports@adonis.osti.gov

Available for sale to the public, in paper, from:

U.S. Department of Commerce

National Technical Information Service

5285 Port Royal Road

Springfield, VA 22161

phone: 800.553 .6847

fax: 703.605.6900

email: orders@ntis.fedworld.gov

online ordering: http://www.ntis.gov/ordering.htm 


\title{
Performance and Reliability of a 1-kW Amorphous Silicon Photovoltaic Roofing System
}

\author{
J. Adelstein and B. Sekulic \\ National Renewable Energy Laboratory, 1617 Cole Blvd., Golden, CO 80401
}

\begin{abstract}
The National Renewable Energy Laboratory (NREL) has been monitoring the performance of a 1- $\mathrm{kW}_{\mathrm{AC}}$ United Solar Systems Corporation (USSC) roofing system over the 6-year period from October 1998 to September 2004. This paper will investigate the performance and reliability of this system. The annual degradation and seasonal fluctuation of the system's power output are calculated using the PVUSA power rating regression model. The system performance is also examined using the additional performance parameters of yield, reference yield, and performance ratio, which allows for a somewhat less complicated data collection and analysis. The data indicate that the system has exhibited stable performance over time, with an overall degradation rate comparable to that found in crystalline silicon systems.
\end{abstract}

\section{Introduction}

This paper describes the performance, based on various performance parameters, of the $1.2-\mathrm{kW}_{\mathrm{DC}}$ USSC roofing system being monitored at NREL over the 6-year period from October 1998 to September 2004. The PV roofing system consists of 72 triple-junction amorphous silicon (a-Si) SHR-17 shingles / modules manufactured by United Solar Systems Corporation (USSC), which perform both as conventional roofing shingles and as a solarelectric array. The 12 "-wide by 86.5 "-long shingles are arranged into two 612-W sub-arrays consisting of 6 strings of 6 shingles / modules. Each sub-array is mounted on a south-facing simulated attic / roof at tilt angle from the horizontal of $40^{\circ}$ (NREL's approximate latitude). The system is connected to the utility grid through a $4-\mathrm{kW}$ Trace Engineering SW4048 inverter.

Experimental in-situ data for the USSC system, as well as wind speed data from NREL's Reference Meteorological and Irradiance System (RMIS), are recorded by Campbell Scientific data acquisition systems (DAS). Measurements are made every $5 \mathrm{~s}$ and stored as 15-min averages for the USSC system and 1-min averages for the RMIS wind speed data. Data collected for the USSC system include: plane-of-array (POA) irradiance, DC voltage, DC current, AC power, and ambient temperature. DC power is calculated by the DAS by multiplying the DC voltage and DC current.

\section{System Description}

The PV shingle array consists of 72 USSC SHR-17 shingle modules divided into two sub-arrays. Each shingle module provides a peak rated power output of $17.3 \mathrm{~W}(2.0$ amps at 8.5 volts) at $1000 \mathrm{~W} / \mathrm{m}^{2}$. Each sub-array consists of 6 parallel strings of $6 \mathrm{PV}$ shingles connected in series and is mounted on a south-facing simulated attic / roof at tilt angle from the horizontal of $40^{\circ}$ (NREL's approximate latitude). The two sub-arrays are joined in a combiner box and connected to the utility grid through a 4-kW Trace Engineering SW4048 inverter.

The DAS system is based on a Campbell Scientific 21XL datalogger. System AC and $D C$ voltages are measured with Ohio Semitronics, Inc. (OSI), model VT8 variable-frequency voltage transducers. System currents are measured with OSI model CTL Hall effect current transducers coupled with model CTA signal conditioners. AC power is measured with an OSI model PC8 variablefrequency watt transducer. Irradiance is measured with a Kipp and Zonen CM11 pyranometer. Ambient temperature is measured with a Campbell Scientific 107 thermistor temperature probe, and wind speed is measured with a Campbell Scientific 03001 Wind Sentry Wind Set.

The system installation was completed on June 30 , 1998, and data acquisition started on July 1, 1998. However, due to an incorrect pyranometer calibration factor, data prior to October 22, 1998, was found to be invalid. Hence, the dataset used for this paper includes data from October 1998 through September 2004. There have been no reliability problems related to the shingles / modules during the time period of this study.

\section{PVUSA power rating analysis}

The PVUSA rating system is based on the assumption that array current primarily depends on irradiance and that array voltage primarily depends on array temperature-which, in turn, depends on array temperature, ambient temperature, and wind speed [2]. Measured data can be used to calculate a best-fit correlation to the following equation:

$$
P=I_{P O A}\left(a+b l_{P O A}+c T_{a m b}+d W\right) \text {, }
$$


where:

$$
\begin{aligned}
\mathrm{P}= & \text { power }(\mathrm{AC} \text { or } \mathrm{DC}), \mathrm{kW} \\
\mathrm{I}_{\mathrm{POA}}= & \mathrm{POA} \text { irradiance, } \mathrm{W} / \mathrm{m}^{2} \\
\mathrm{~T}_{\mathrm{amb}}= & \text { ambient temperature },{ }^{\circ} \mathrm{C} \\
\mathrm{W}= & \text { wind speed, } \mathrm{m} / \mathrm{s} \\
\mathrm{a}, \mathrm{b}, \mathrm{c}, \mathrm{d}= & \text { regression coefficients derived } \\
& \text { from operational data }
\end{aligned}
$$

One-month blocks of 15-min average system performance and meteorological observations were used to obtain the regression coefficients above. Because the PVUSA model performance is poor at low irradiances, the $P O A$ irradiance inputs to the regression equation were restricted to $\mathrm{I}_{\mathrm{POA}}>800 \mathrm{~W} / \mathrm{m}^{2}$. The measured power was restricted to $\mathrm{P}_{\mathrm{DC}}>800 \mathrm{~W}$ and $\mathrm{P}_{\mathrm{AC}}>700 \mathrm{~W}$, in an attempt to filter out data that were collected when there was snow covering the array.

After determining the regression coefficients, we found the PVUSA power rating for the system for each one month block by normalizing to PVUSA test conditions (PTC), where PTC conditions are defined as $1000 \mathrm{~W} / \mathrm{m}^{2}$ POA irradiance, $20^{\circ} \mathrm{C}$ ambient temperature, and $1 \mathrm{~m} / \mathrm{s}$ wind speed.

National Instrument's LabVIEW programs originally developed at NREL by Keith Emery and modified for this paper were used to combine the USSC data with the RMIS wind speed data and to perform the linear regression. LabVIEW's general linear-fit function was used to determine the set of linear coefficients using the least chi-square method. Monthly power ratings are then plotted to show the system performance vs. time.

\section{Other System Performance Indices}

Marion et al [3] present three parameters that can define the overall performance of a PV system with respect to energy production and the solar resource. These parameters, defined in the International Electrotechnical Commission (IEC) Standard 61724 [5], are the final $P V$ system yield $\left(Y_{f}\right)$, reference yield $\left(Y_{r}\right)$, and performance ratio (PR). follows:

The values for $Y_{f}, Y_{r}$, and $P R$ are calculated as

$$
Y_{f}=E_{A C} / P_{O}(k W h / k W \text { or hours })
$$

$$
\begin{aligned}
& Y_{r}=\operatorname{Irr} / \text { ref Irr (hours) } \\
& P R=Y_{f} / Y_{r} \text { (dimensionless) }
\end{aligned}
$$

where:

$$
\begin{aligned}
& \mathrm{E}_{\mathrm{AC}}=\text { system net } \mathrm{AC} \text { energy output in } \mathrm{kWh} \\
& \mathrm{P}_{\mathrm{o}}=\text { system rated power in } \mathrm{kW} \\
& \mathrm{Irr}=\text { total plane of array irradiance in } \mathrm{kWh} / \mathrm{m}^{2} \\
& \text { ref Irr }=\text { reference irradiance (usually } 1 \mathrm{~kW} / \mathrm{m}^{2} \text { ) }
\end{aligned}
$$

The final yield $\left(\mathrm{Y}_{\mathrm{f}}\right)$ represents the number of hours that the PV array would need to operate at its rated power to produce that amount of energy. The reference yield $\left(Y_{r}\right)$ represents the equivalent amount of hours necessary for the array to receive the reference irradiance. The performance ratio (PR) is thus the ratio of the measured system energy to the hypothetical energy that would be produced had the system been operating at its rated power under the reference irradiance. It indicates the energy output that may be realized under typical field conditions. By normalizing with respect to irradiance, the PR quantifies the overall effect of losses on the rated output due to inverter inefficiency, wiring mismatch, and other losses due to the DC-to-AC power conversion, module reflection losses, and soiling losses [3].

The same one-month blocks of 15-min average system performance and meteorological observations were used to calculate and plot the monthly performance ratios for the USSC system. Choosing the performance ratio versus the PVUSA power rating as a performance metric simplifies both the data collection, by eliminating the need to measure and record the ambient temperature and wind speed, and analysis, by eliminating the regression model.

\section{Results and Discussion}

Figure 1 depicts the PVUSA AC and DC power ratings of the USSC system vs. time from October 1998 through September 2004 for irradiances greater than 800 $\mathrm{W} / \mathrm{m}^{2}$ and system power greater than 700

$\mathrm{W}_{\mathrm{AC}}$ and $800 \mathrm{~W}_{\mathrm{DC}}$. 


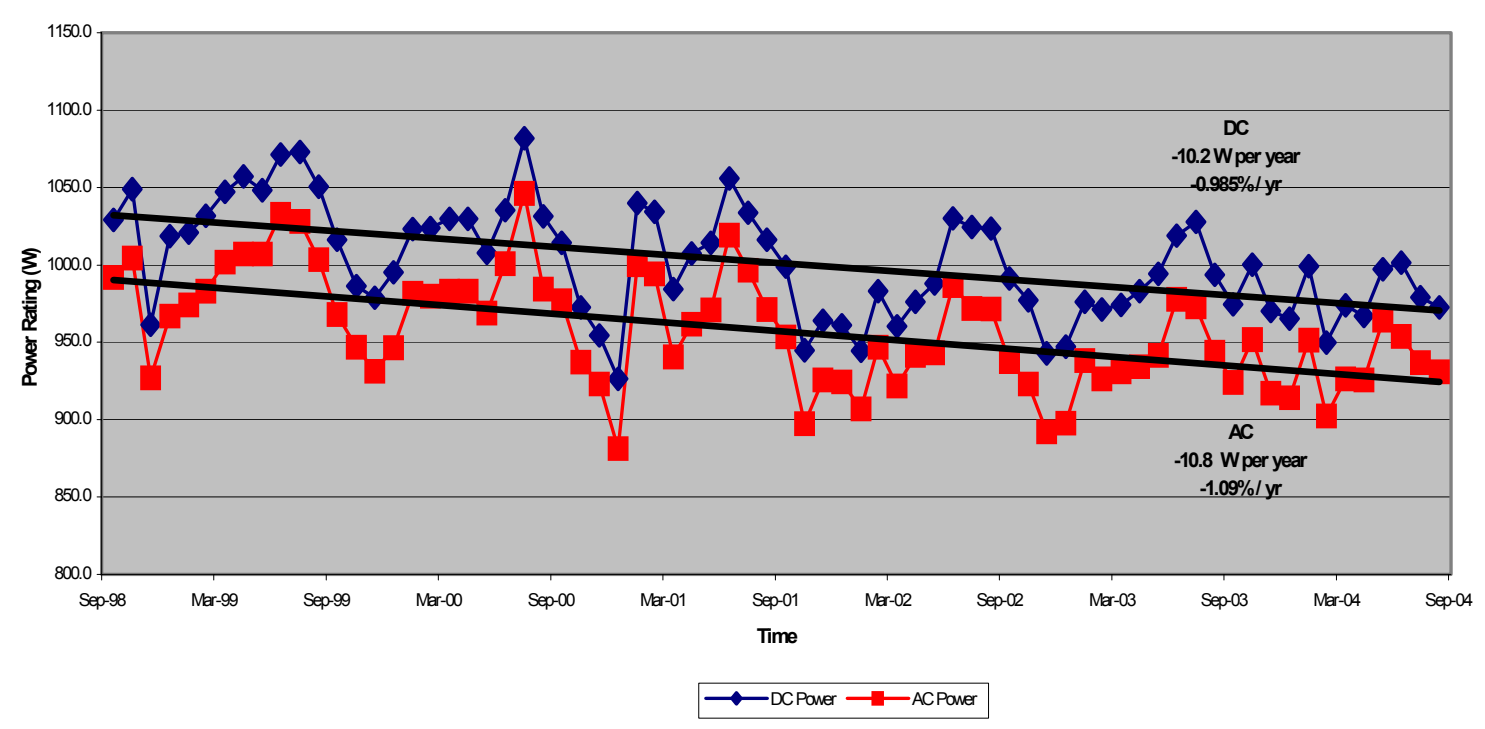

Figure 1: USSC Roof - PVUSA Power Rating vs Time $\left(\right.$ Irr $>800 \mathrm{~W} / \mathrm{m}^{2}$ and $\left.\mathrm{P}>800 \mathrm{~W}(\mathrm{P}>700 \mathrm{~W} A C)\right)$.

Linear fits to the power rating curves indicate that the USSC roof system has degraded at a rate of $10.2 \mathrm{~W}$ $(0.985 \%)$ per year DC and $10.8 \mathrm{~W}(1.09 \%)$ per year AC over the 6-year time period from October 1998 through September 2004. Amorphous silicon modules typically experience a light-induced performance degradation on initial exposure due to the Staebler-Wronski effect [4]. In a paper summarizing performance characterization of a$\mathrm{Si}$ modules from several manufacturers, Sandia National Laboratories found that previously unexposed a-Si modules showed an initial rapid degradation in power over the first 6 months and reached a "stabilized" power level, about $20 \%$ below the initial $\left(1^{\text {st }}\right.$ day) power after about one year. Seasonal oscillation is usually $\pm 4 \%$ from the "stabilized" level [1]. Because the shingles I modules had been deployed for several months before accurate data acquisition began, the initial rapid degradation characteristic of a-Si modules was not observed; however, the system demonstrates the typical seasonal oscillating power output also characteristic of a-Si modules, i.e., higher power output in the warmer summer months. Yearly DC seasonal variation for this system was found to average $+4.9 \%$ and $-5.4 \%$ from the yearly mean power rating for the five complete years of data available (1999 through 2003).
The system performance ratio (PR) is plotted in Fig. 2, along with a scaled version of the AC PVUSA power-rating plot for comparison. A linear fit for the PR for the 6-year time period from September 1998 through September 2004 indicates a degradation rate of $1.13 \%$ per year, which corresponds well with the degradation rate of the PVUSA AC power rating of $-1.09 \%$. The positive yearly seasonal oscillation averaged $4.6 \%$, similar to that of the PVUSA method; however, the negative value averaged $-7.8 \%$, somewhat greater than that found with the PVUSA method.

Note that the typical winter power-rating decline does not appear to have occurred over the 2003 / 2004 winter season when using the PVUSA method. Upon further investigation of the data, we noted that for two of the winter months_in particular, November 2003 and February 2004-daily high temperatures for a few days were in the $-15^{\circ}$ to $-20^{\circ} \mathrm{C}$ range. The average temperature recorded by RMIS between 1994 and 2004 is $1.7^{\circ} \mathrm{C}$ in February and $4.9^{\circ} \mathrm{C}$ in November. It is possible that such a large extrapolation from $20^{\circ} \mathrm{C}$, which is the standard for PTC, yielded questionable results. 


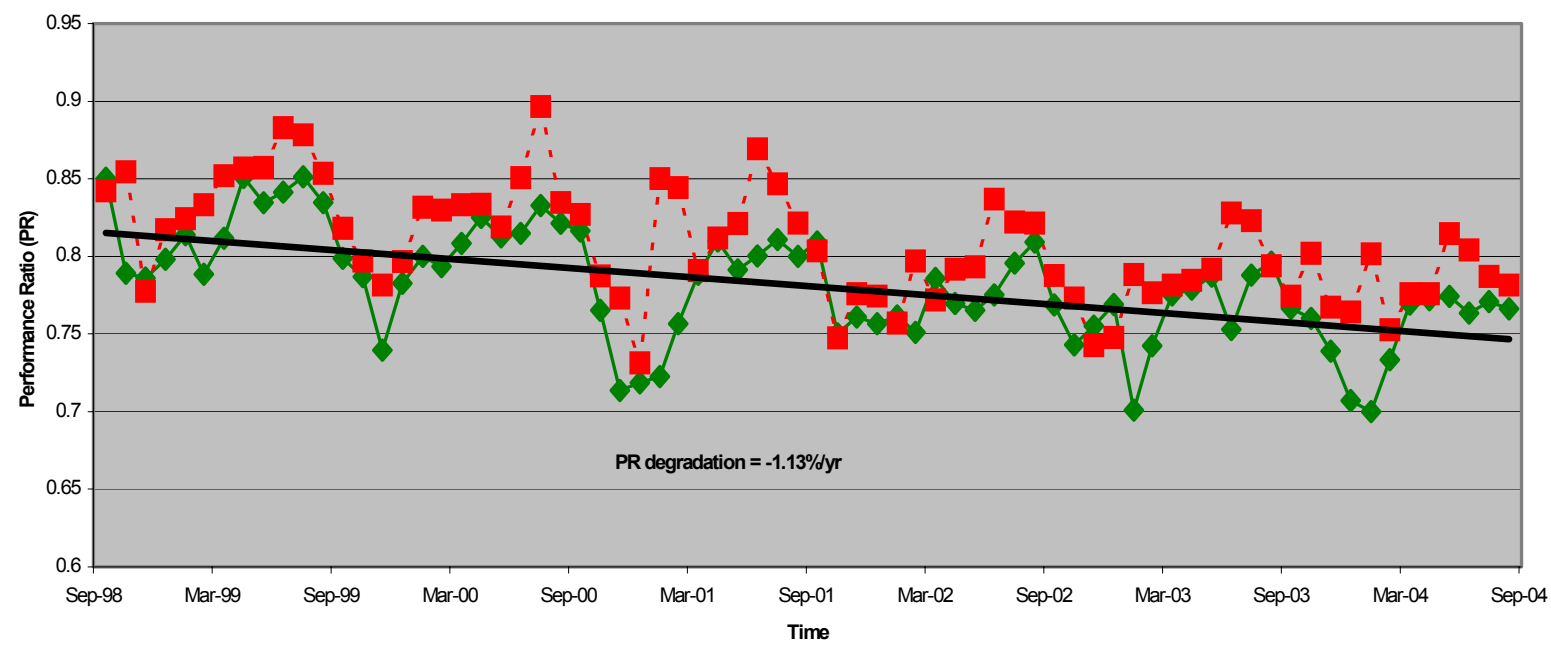

\section{—-Performance Ratio -.. - - Scaled PVUSA AC Power Rating}

Figure 2: USSC Roof System Performance Ratio vs. Time.

\section{Conclusions}

The performance monitoring of the USSC a-Si triplejunction SHR-17 roofing system at NREL over a 6-year period has shown the shingles / modules to have excellent reliability and degradation trends comparable to those for crystalline $\mathrm{Si}$ modules. The degradation rate was determined to be $0.985 \%$ per year (DC) and $1.09 \%$ per year (AC) by the PVUSA method and $1.13 \%$ (AC) by the performance ratio (PR) method. Season variation was found to be about 10.5\% (PVUSA method) and 12.5\% (PR method).

\section{References}

1. D. King, J. Kratochvil, and W. Boyson. "Stabilization and Performance Characteristics of Commercial Amorphous-Silicon PV Modules," Proc. $28^{\text {th }}$ IEEE PVSC, 2000, p.1446-1449.
2. C.M. Whitaker T.U. Townsend, "Application and Validation of a New PV Performance Characterization Method," Proc. $26^{\text {th }}$ IEEE PVSC, 1997, p.1253-1256.

3. B. Marion, et al., "Performance Parameters for Grid-Connected PV Systems," Proc. $31^{\text {st }}$ IEEE PVSC, 2005 (in press).

4. D.L. Staebler and C.R. Wronski, "Reversible Conductivity Changes in Discharge-Produced Amorphous Si," Appl. Phys. Lett. 31, 292-294 (1977).

5. IEC, "Photovoltaic system performance monitoring guidelines for measurement, data exchange and analysis, IEC Standard 61734", Geneva, Switzerland, 


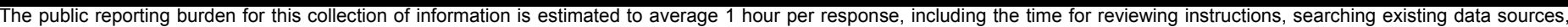

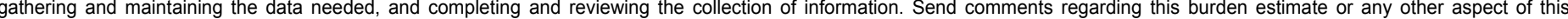

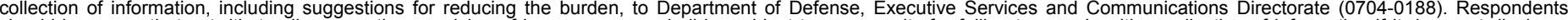

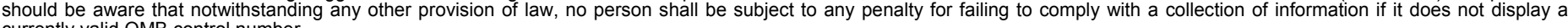
currently valid OMB control number.

PLEASE DO NOT RETURN YOUR FORM TO THE ABOVE ORGANIZATION.

\section{REPORT DATE (DD-MM-YYYY) February 2005 \\ 2. REPORT TYPE \\ Conference Paper}

4. TITLE AND SUBTITLE

Performance and Reliability of a 1-kW Amorphous Silicon

Photovoltaic Roofing System
3. DATES COVERED (From - To) 5a. CONTRACT NUMBER

DE-AC36-99-G010337

5b. GRANT NUMBER

5c. PROGRAM ELEMENT NUMBER

5d. PROJECT NUMBER

NREL/CP-520-36583

5e. TASK NUMBER

PVC57101

5f. WORK UNIT NUMBER
7. PERFORMING ORGANIZATION NAME(S) AND ADDRESS(ES)

National Renewable Energy Laboratory

1617 Cole Blvd.

Golden, CO 80401-3393
8. PERFORMING ORGANIZATION REPORT NUMBER

NREL/ CP-520-36583

9. SPONSORING/MONITORING AGENCY NAME(S) AND ADDRESS(ES)

10. SPONSOR/MONITOR'S ACRONYM(S) NREL

11. SPONSORING/MONITORING AGENCY REPORT NUMBER

\section{DISTRIBUTION AVAILABILITY STATEMENT}

National Technical Information Service

U.S. Department of Commerce

5285 Port Royal Road

Springfield, VA 22161

\section{SUPPLEMENTARY NOTES}

\section{ABSTRACT (Maximum 200 Words)}

The National Renewable Energy Laboratory (NREL) has been monitoring the performance of a 1- $\mathrm{kW}_{\mathrm{AC}}$ United Solar Systems Corporation (USSC) roofing system over the 6-year period from October 1998 to September 2004. This paper will investigate the performance and reliability of this system. The annual degradation and seasonal fluctuation of the system's power output are calculated using the PVUSA power rating regression model. The system performance is also examined using the additional performance parameters of yield, reference yield, and performance ratio, which allows for a somewhat less complicated data collection and analysis. The data indicate that the system has exhibited stable performance over time, with an overall degradation rate comparable to that found in crystalline silicon systems.

\section{SUBJECT TERMS}

PV; performance and reliability; power rating regression model; crystalline silicon

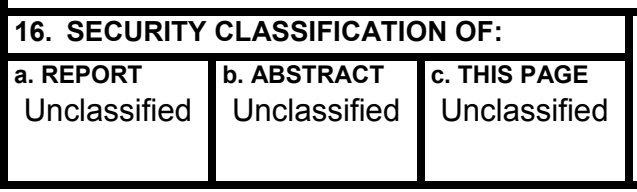

17. LIMITATION
OF ABSTRACT
UL

18. NUMBER
OF PAGES

19a. NAME OF RESPONSIBLE PERSON

19b. TELEPONE NUMBER (Include area code) 